\title{
PENGARUH PERUBAHAN TUTUPAN LAHAN MANGROVE DAN TOTAL SUSPENDED SEDIMENT TERHADAP DINAMIKA GARIS PANTAI TIKU KABUPATEN AGAM
}

\author{
Devira Frissilla Milton ${ }^{1}$, Helfia Edial ${ }^{2}$, Triyatno $^{2}$ \\ Program Studi Geografi, \\ Falkutas Ilmu Sosial, Universitas Negeri Padang \\ Email : devira.milton@gmail.com
}

\begin{abstract}
ABSTRAK
Penelitian ini bertujuan untuk mengetahui perubahan luas tutupan lahan mangrove, mengetahui total suspended sediment, menganalisis dinamika garis pantai, dan mengetahui pengaruh perubahan luas tutupan lahan mangrove dan Total suspended sediment terhadap dinamika garis pantai Kecamatan Tanjung Mutiara. Jenis penelitian ini adalah metode deskriptif kuantitatif. Teknik analisis data menggunakan teknik klasifikasi citra model terbimbing dan tidak terbimbing untuk analisis tutupan lahan mangrove dan total suspended sediment (TSS) serta metode overlay untuk analisis dinamikan garis pantai. Hasil penelitian memperlihatkan bahwa (1) luas tutupan lahan mangrove pada kawasan pesisir Tiku tahun 1993 seluas 885,95 Ha dan tahun 2017 menjadi seluas 327,97 Ha. (2) nilai rata-rata konsentrasi TSS tahun 1993 sebesar 20,31 mg/l dan tahun 2017 menjadi sebesar 105,11 mg/l. (3) Garis pantai kawasan pesisir Tiku dari tahun 1988 hingga tahun 2017 mengalami perubahan rata-rata selebar 60,27 m. (4) Berdasarkan hasil analisis statistik regresi, maka dapat disimpulkan bahwa : a) $\mathrm{H} 1$ diterima, berarti terdapat pengaruh antara variabel mangrove terhadap variabel garis pantai. b) H1 ditolak, berarti tidak terdapat pengaruh variabel TSS terhadap variabel garis pantai. c) H1 diterima, berarti terdapat pengaruh variabel mangrove dan variabel TSS secara simultan terhadap variabel garis pantai sebesar 90,5\%.
\end{abstract}

Kata Kunci: Tutupan Lahan Mangrove, TSS, Dinamika garis pantai

\begin{abstract}
The purpose of this research is to know the change of mangrove cover area, to know the total suspended sediment, to analyze the dynamics of coastline, and to know the effect of the change of mangrove land cover area and total suspended sediment towards the dynamics of Tanjung Mutiara Subdistrict. The type of this research is quantitative descriptive method. The data analysis technique uses guided and unbranded modeled image classification techniques for mangrove land cover analysis and total suspended sediment (TSS) as well as overlay method for shoreline dynamic analysis. The results showed that (1) the area of mangrove land cover in coastal area of Tiku in 1993 was $885.95 \mathrm{Ha}$ and 2017 became $327.97 \mathrm{Ha}$. (2) the average value of TSS concentration in 1993 was $20.31 \mathrm{mg} / \mathrm{l}$ and 2017 to $105.11 \mathrm{mg} / \mathrm{l}$. (3) Coastline of coastal area of Tiku from 1988 to 2017 experienced an average change as wide as $60.27 \mathrm{~m}$. (4) Based on the results of regression statistical analysis, it can be concluded that: a) H1 accepted, means there is influence between mangrove variables to coastline variables. b) HI is rejected, meaning there is no influence of TSS variable to coastline variable. c) HI accepted, means there is influence of mangrove variables and TSS variables simultaneously to coastal line variables of $90.5 \%$.
\end{abstract}

Keywords: Mangrove Land Cover, TSS, Coastline Dynamics

\footnotetext{
${ }^{1}$ Mahasiswa Geografi Fakultas Ilmu Sosial Univesitas Negeri Padang

${ }^{2}$ Dosen Geografi Fakultas Ilmu Sosial Univesitas Negeri Padang. Drs. Helfia Edial, MT, Triyatno, S.Pd, M.Si
} 


\section{PENDAHULUAN}

Wilayah pesisir adalah suatu wilayah peralihan (interface area) antara ekosistem daratan dan laut. (Effendy, 2009). Menurut UU No 27 Tahun 2007, wilayah pesisir adalah daerah peralihan antara ekosistem darat dan laut yang dipengaruhi oleh perubahan di darat dan laut.

Seluas 86 hektare dari 313,5 ha hutan mangrove atau bakau di sepanjang garis pantai Kabupaten Agam, Sumatera Barat, dalam kondisi rusak akibat alih fungsi lahan menjadi perkebunan kelapa sawit. Hutan mangrove yang rusak ini tersebar di Nagari Tiku Selatan dan Tiku Lima Jorong, Kecamatan Tanjung Mutiara. (Ermanto, 2016).

Pada pertengahan 2016, sekitar 12 meter bibir pantai terkikis ombak dan mengakibatkan 260 batang pohon kelapa tumbang. Kondisi ini sudah terjadi semenjak 2012. Pantai Jorong Ujung Labung, Kecamatan Tanjung Mutiara, Kabupaten Agam mengalami abrasi yang cukup parah, meskipun di daerah tersebut sudah dipasang batu krip berukuran besar. Panjang pantai yang terkena abrasi sudah mencapai 60 meter yang merusak 10 ribu $\mathrm{m}^{2}$ hutan mangrove (Lukman, 2016).

Perakaran mangrove yang rapat dan terpancang dapat berfungsi efektif dalam menangkap partikel-partikel tanah dan sedimen yang berasal dari erosi daratan. Lumpur yang terbawa air dari daratan akan terperangkap oleh akar mangrove dan mengendapkannya sehingga akan terjadi suatu kondisi dimana endapan lumpur tidak hanyut oleh arus dan gelombang laut. Lumpur yang terperangkap oleh perakaran mangrove makin lama akan semakin tebal sehingga lama kelamaan akan terbentuk lahan baru ke arah laut. Contohnya, pantai timur Sumatera yang ditumbuhi mangrove, penambahan daratan kearah laut sekitar $2 \mathrm{~cm} /$ tahun.

Keberadaan mangrove akan perluasan wilayah ke arah laut walaupun dalam kurun waktu yang lama. Ini sangat menguntungkan, karena ekosistem mangrove yang tebal akan menambah luas ekosistem tersebut sehingga kondisi pantai akan menjadi stabil. Akar tumbuhan mangrove menangkap partikel tanah, sehingga dasar perairan menjadi berlumpur. Karenanya begitu buah dari tumbuhan mangrove jatuh akan langsung menancap dan menjadi tumbuhan baru. Regenerasi ini akan berlangsung terusmenerus, kecuali mendapat ancaman dari manusia.

Berdasarkan analisis citra satelit menggunakan teknik pengindraan jauh, kita dapat mengetahui seberapa besar pengaruh dari masing-masing variabel tersebut yaitu pengaruh tutupan lahan mangrove dan sedimen yang tersuspensi dan diendapkan oleh akan mangrove terhadap perubahan morfologis garis pantai.

\section{METODE PENELITIAN}

Penelitian ini merupakan penelitian deskriptif kuantitatif dengan menganalisis data spasial pengindraan jauh.

Jenis data yang digunakan dalam penelitian ini merupakan data primer dan data sekunder. Data primer berupa pengambilan sampel total suspended sediment dilapangan. Data sekunder 
berupa citra landsat $5 \mathrm{TM}$ dan landsat 8 OLI/TIRS tahun 1993, 2005 dan 2017.

Teknik penentuan sampel yang digunakan dalam penelitian ini adalah teknik purposive sampling, sesuai dengan kriteria sampel yang diperlukan.

Dalam menentukan titik pengambilan sampel suspended sediment, terlebih dahulu dilakukan analisis citra tidak terbimbing tahap awal. Dikarenakan keterbatasan waktu, pengetahuan dan kemampuan yang peneliti miliki, kemudian peneliti membatasi bahwa pengambilan sampel TSS dilakukan pada pada air permukaan dengan kedalaman antara 0,5 - 1 meter dari permukaan air, serta pengambilan sampel dilakukan pada daerah bermangrove dan bekas mangrove.

Teknik pengumpulan data yang digunakan adalah data citra satelit yang diperoleh dari sebuah agensi ilmiah milik pemerintahan Amerika Serikat yaitu United States Geological Survey (USGS) berupa citra Landsat $5 \mathrm{TM}$ tahun 1993 dan tahun 2005 serta Landat OLI 8 tahun 2017 dan data suspended sediment dalam penelitian ini diperoleh dengan cara melakukan pengambilan sampel di lapangan. Tahap selanjutnya dilakukan uji labor terhadap sampel untuk melihat suspended sediment yang terkandung dalam setiap liter sampel dengan berpatokan kepada keputusan Menteri Negara Lingkungan Hidup Nomor 51 Tahun 2004 tentang Baku Mutu Air Laut pada kawasan mangrove yaitu $80 \mathrm{mg} / \mathrm{l}$.

Teknik analisis data yang digunakan adalah teknik analisis citra dengan memanfaatkan teknik analisis pengindraan jauh untuk mengetahui perubahan luas dan kerapatan vegetasi mangrove, total suspended sediment dan dinamika garis pantai. Sedangkan untuk melihat pengaruh perubahan luas tutupan lahan mangrove dan total suspended sediment terhadap dinamika garis pantai dilakukan dengan memanfaatkan analisis stastistik korelasi sederhana.

\section{HASIL DAN PEMBAHASAN}

Tanjung Mutiara adalah sebuah kecamatan yang terletak pada kabupaten Agam, provinsi Sumatera Barat. Berdasarkan letak astronomis Kecamatan Tanjung Mutiara terletak diantara $0^{0} 10^{\prime}$ LS - $0^{0} 26^{\prime}$ LS dan $99^{\circ} 46^{\prime}$ BT - $100^{\circ} 00^{\prime}$ BT.

Gambar 1 merupakan peta lokasi penelitian yang terletak pada kawasan pesisir Kecamatan Tanjung Mutiara Kabupaten Agam.

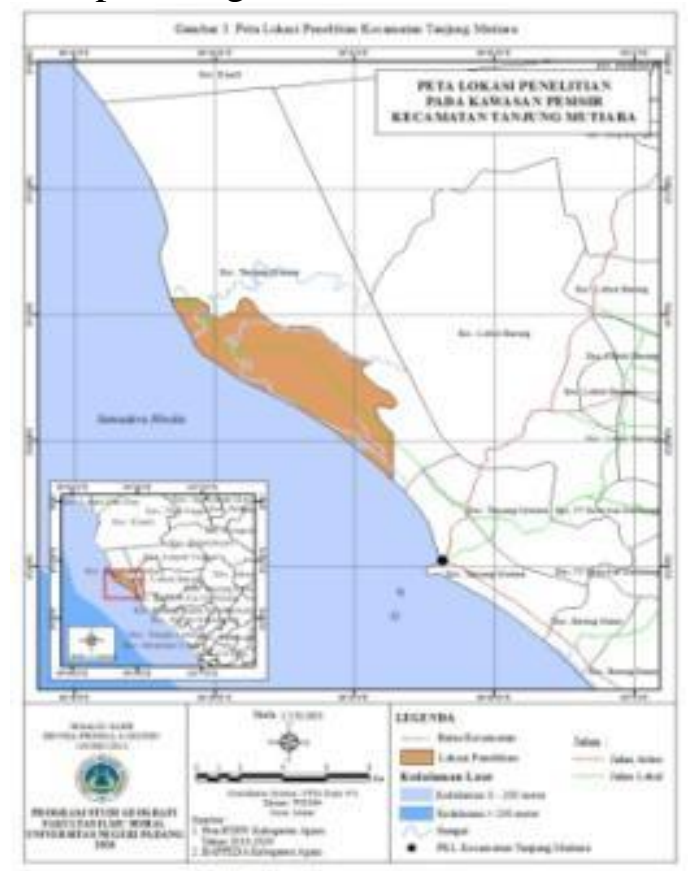

Gambar 1. Peta Lokasi Penelitian Sumber : BAPPEDA Kabupaten Agam 
1. Perubahan Luas Tutupan Lahan Mangrove

a. Tutupan Lahan Mangrove Tahun 1993

Tutupan lahan pada daerah penelitian tahun 1993 terdiri dari tutupan lahan mangrove seluas 885,95 Ha. Tutupan lahan perkebunan seluas 1469,10 Ha. Selanjutnya tanah terbuka seluas 367,36 Ha dan tutupan lahan belukar seluas 820,95 Ha. Dengan total luas lahan pada daerah penelitian yaitu seluas 3543,36 Ha.

Klasifikasi indeks kerapatan mangrove tahun 1993 yang diperoleh dari hasil analisis pengindraan jauh dengan metode NDVI. Pada tabel terlihat bahwa indeks kerapatan $0,30 \mathrm{~s} / \mathrm{d}$ 0,41 termasuk kedalam kelas jarang, 0,41-0,52 termasuk kedalam kelas cukup rapat, 0,52 s/d 0,63 termasuk kedalam kelas rapat, dan 0,63 s/d 0,74 termasuk kedalam kelas sangat rapat.

Gambar 2 merupakan peta tutupan lahan pada daerah penelitian yang diperoleh dari analisis citra landsat 5 TM, dimana peta tersebut menjelaskan mengenai luas tutupan lahan yang terdiri dari lahan terbuka, tutupan lahan mangrove, perkebunan sawit dan belukar dan kelas indeks kerapatan tumbuhan mangrove tahun 1993 pada kawasan pesisir pantai Kecamatan Tanjung Mutiara.

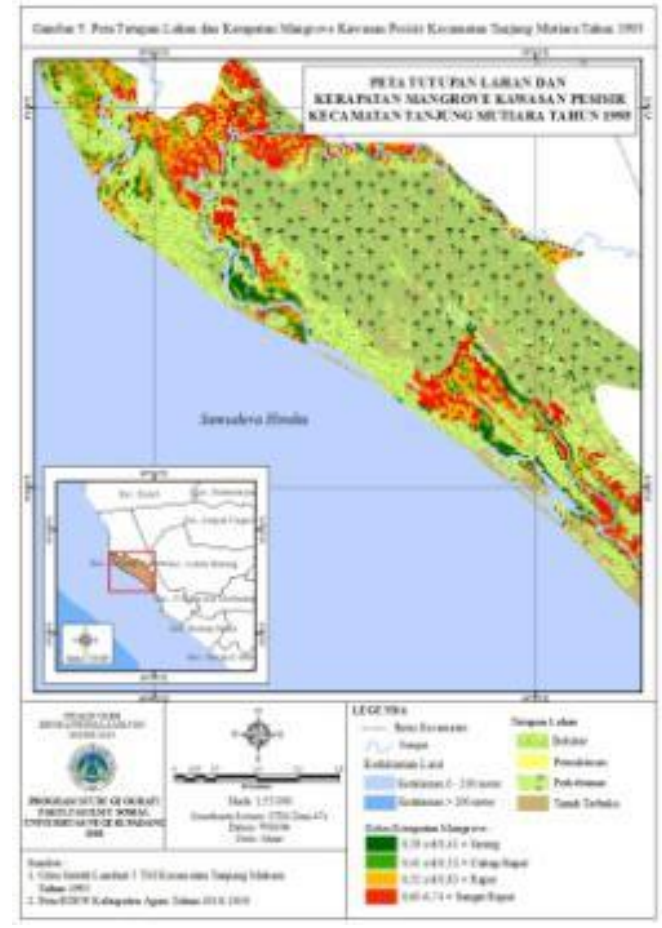

Gambar 2. Peta Tutupan Lahan Dan

Kerapatan Mangrove Tahun 1993

Sumber : Hasil Analisis Citra Landsat 5 TM Tahun 1993

\section{b. Tutupan Lahan Mangrove Tahun 2005}

Tutupan lahan kawasan pesisir Kecamatan Tanjung Mutiara pada tahun 2005 terdiri dari tutupan lahan mangrove seluas 544,23 Ha. Tutupan lahan perkebunan seluas 2062,30 Ha. Selanjutnya tanah terbuka seluas 878,67 Ha dan tutupan lahan pemukiman seluas 58,29 Ha. Dengan total luas lahan pada daerah penelitian yaitu seluas 3543,49 Ha.

Berdasarkan keterangan diatas terlihat adanya pengurangan luas tutupan lahan mangrove dari tahun 1993 hingga tahun 2005 seluas 341,72 Ha. Berdasarkan interpretasi citra dan survey lapangan, terlihat bahwa faktor dominan yang menyebabkan terjadinya penurunan luas tutupan lahan mangrove pada daerah penelitian karena adanya 
perubahan penggunaan lahan mangrove menjadi lahan perkebunan. Selain kegiatan alih fungsi lahan, penebangan pohon mangrove yang tidak sesuai dengan aturannya juga menjadi salah satu faktor penyebab terjadinya penurunan luas tutupan lahan mangrove.

Indeks kerapatan 0,22 s/d 0,33 termasuk kedalam kelas jarang, 0,33 s/d 0,44 termasuk kedalam kelas cukup rapat, 0,44 s/d 0,55 termasuk kedalam kelas rapat, dan 0,55 s/d 0,66 termasuk kedalam kelas sangat rapat.

Gambar 3 merupakan peta tutupan lahan pada daerah penelitian yang diperoleh dari analisis citra landsat 5 TM, dimana peta tersebut menjelaskan mengenai luas tutupan lahan tahun 2005 pada kawasan pesisir pantai Kecamatan Tanjung Mutiara.

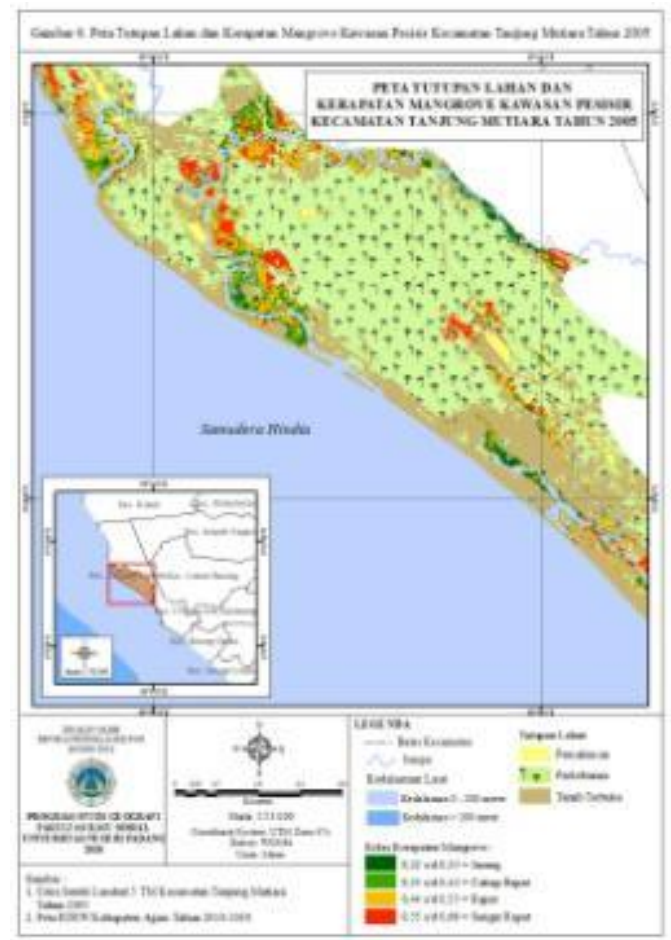

Gambar 3. Peta Tutupan Lahan Dan Kerapatan Mangrove Tahun 2005 Sumber : Hasil Analisis Citra Landsat 5 TM Tahun 2005 c. Tutupan Lahan Mangrove Tahun 2017

Berdasarkan hasil analisis citra landsat 8 OLI/TIRS pada tahun 2017 diperoleh informasi mengenai luas tutupan lahan mangrove dan non mangrove pada daerah penelitian.

Tutupan lahan kawasan pesisir Kecamatan Tanjung Mutiara pada tahun 2017 terdiri dari tutupan lahan mangrove seluas 327,97 Ha. Tutupan lahan perkebunan seluas 2578,26 Ha. Selanjutnya tanah terbuka seluas 564,28 Ha dan tutupan lahan pemukiman seluas 73,16 Ha. Dengan total luas lahan pada daerah penelitian yaitu seluas 3543,67 Ha.

Berdasarkan keterangan diatas terlihat adanya pengurangan luas tutupan lahan mangrove dari tahun 2005 hingga tahun 2017 seluas 216,26 Ha sama halnya dengan periode tahun sebelumnya. Berdasarkan interpretasi citra dan survey lapangan, terlihat bahwa alih fungsi lahan dari lahan mangrove menjadi perkebunan serta penebangan dan pemanfaatan ekosistem mangrove yang tidak memperhatikan kelestarian mangrove masih menjadi faktor dominan penyebab terjadinya penurunan luas tutupan lahan mangrove pada daerah penelitian.

Indeks kerapatan -0,08 s/d 0,09 termasuk kedalam kelas jarang, 0,09 s/d 0,26 termasuk kedalam kelas cukup rapat, 0,26 s/d 0,43 termasuk kedalam kelas rapat, dan 0,43 s/d 0,60 termasuk kedalam kelas sangat rapat.

Gambar 4 merupakan peta tutupan lahan pada daerah penelitian yang diperoleh dari analisis citra landsat 8 
OLI/TIRS, dimana peta tersebut menjelaskan mengenai luas tutupan lahan tahun 2017 pada kawasan pesisir pantai Kecamatan Tanjung Mutiara.

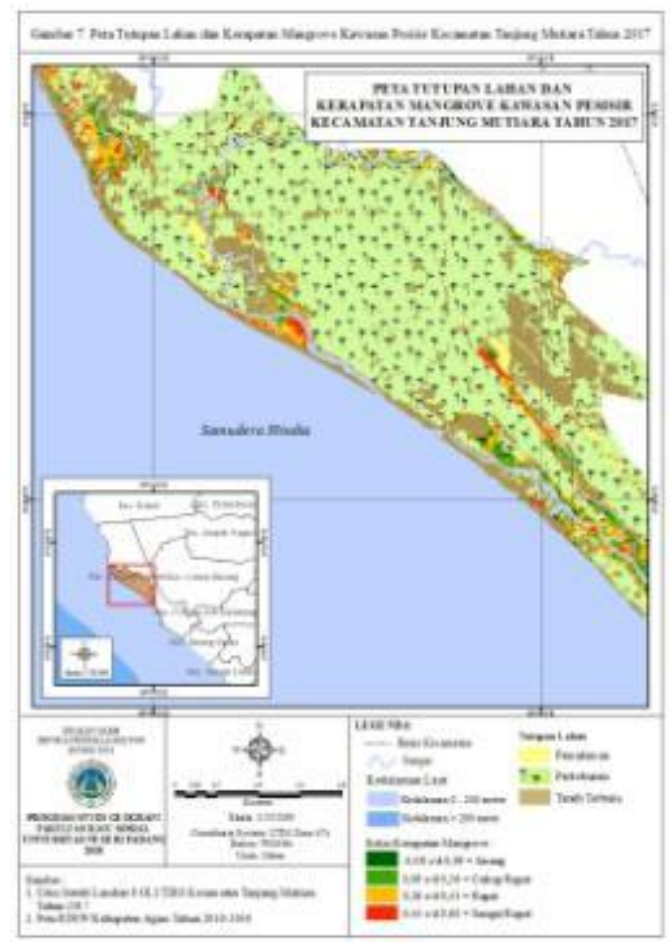

Gambar 4. Peta Tutupan Lahan Dan

Kerapatan Mangrove Tahun 2017

Sumber : Hasil Analisis Citra Landsat 8 OLI/TIRS Tahun 2017

Berdasarkan dari hasil analisis citra tutupan lahan kawasan pesisir Kecamatan Tanjung Mutiara pada tahun 1993, tahun 2005 dan tahun 2017, maka diperoleh informasi mengenai perubahan luasan tutupan lahan mangrove selama kurun waktu kurang lebih 24 tahun.

Tabel 1.

Perubahan Luas Tutupan Lahan Mangrove Tahun 1993, 2005 Dan 2017

\begin{tabular}{|c|c|c|}
\hline No & Tahun & $\begin{array}{c}\text { Perubahan Luas } \\
\text { Tutupan Lahan } \\
\text { Mangrove (Ha) }\end{array}$ \\
\hline 1 & 1993 & 885,95 \\
\hline 2 & 2005 & 544,23 \\
\hline 3 & 2017 & 327,97 \\
\hline
\end{tabular}

Sumber : Hasil Analisis Citra Landsat 5 TM Dan Landsat 8 OLI/TIRS

Berdasarkan keterangan diatas

Dari tabel 1 diketahui bahwa terjadi penurunan luas tutupan lahan mangrove pada kawasan pesisir Kecamatan Tanjung Mutiara dalam kurun waktu 24 tahun. Dimana pada tahun 1993 tutupan lahan mangrove pada daerah penelitian memiliki luas 885,95 Ha, tahun 2005 memiliki luas 544,23 Ha dan tahun 2017 luasnya 327,97 Ha. diketahui bahwa jumlah pengurangan luas tutupan lahan mangrove dari tahun 1993 hingga 2005 sebesar $341.72 \mathrm{Ha}$ sedangkan dari tahun 2017 hingga 2005 sampai 2017 berkurang $216.26 \mathrm{Ha}$.

Berdasarkan hasil interpretasi citra dan survey lapangan di ketahui bahwa pengurangan luas lahan terjadi karena alih fungsi lahan menjadi lahan perkebunan dan pemanfaatan hutan mangrove yang tidak memperhatikan 
kelestariannya serta akibat abrasi pantai pada kawasan pesisir Kecamatan Tanjung Mutiara.

\section{Prediksi Total Suspended Sediment}

a. Total Suspended Sediment Hasil Pengukuran Lapangan

Pengambilan sampel lapangan digunakan sebagai data pendukung untuk validasi data hasil analisis citra. Validasi data dilakukan dengan mencocokkan nilai kandungan TSS hasil pengukuran lapangan dengan kandungan TSS hasil analisis citra landsat 8 OLI/TIRS tahun 2017 yang diklasifikasikan menjadi 4 kelas, yang termasuk kedalam kelas I adalah TSS dengan kode UL1 memiliki nilai kandungan TSS sebasar 34,99 mg/l, UL2 sebesar 20,49 mg/l, dan UL3 sebesar 12,08 mg/l. Kelas II terdiri dari TSS dengan kode Ms2 sebesar 121,19 mg/l, An1 sebesar 104,49 mg/l dan An2 sebesar 91,69 mg/l. Kelas III terdiri dari TSS dengan kode Ms1 sebesar 178,78 mg/l, Ms3 sebesar 134,99 mg/l. Kelas IV terdiri dari TSS dengan kode An3 sebesar 247,28 mg/l.

Berdasarkan hasil survey lapangan diketahui bahwa nilai konsentrasi TSS lebih rendah pada daerah yang memiliki tumbuhan mangrove lebih banyak. Sedangkan pada daerah yang memiliki tumbuhan mangrove lebih sedikit, nilai konsentrasi TSS nya lebih tinggi hingga melebihi ambang batas nilai konsentrasi TSS yang diperbolehkan oleh Mentri Lingkungan Hidup yaitu $80 \mathrm{mg} / \mathrm{l}$ untuk kawasan mangrove.

Gambar 5 merupakan peta titik pengambilan sampel TSS dilapangan yang diperoleh dari analisis citra landsat 8 OLI/TIRS tahun 2017, dimana peta tersebut menjelaskan mengenai titik sampel lapangan dan kelas konsentrasi TSS tahun 2017 pada kawasan pesisir pantai Kecamatan Tanjung Mutiara.

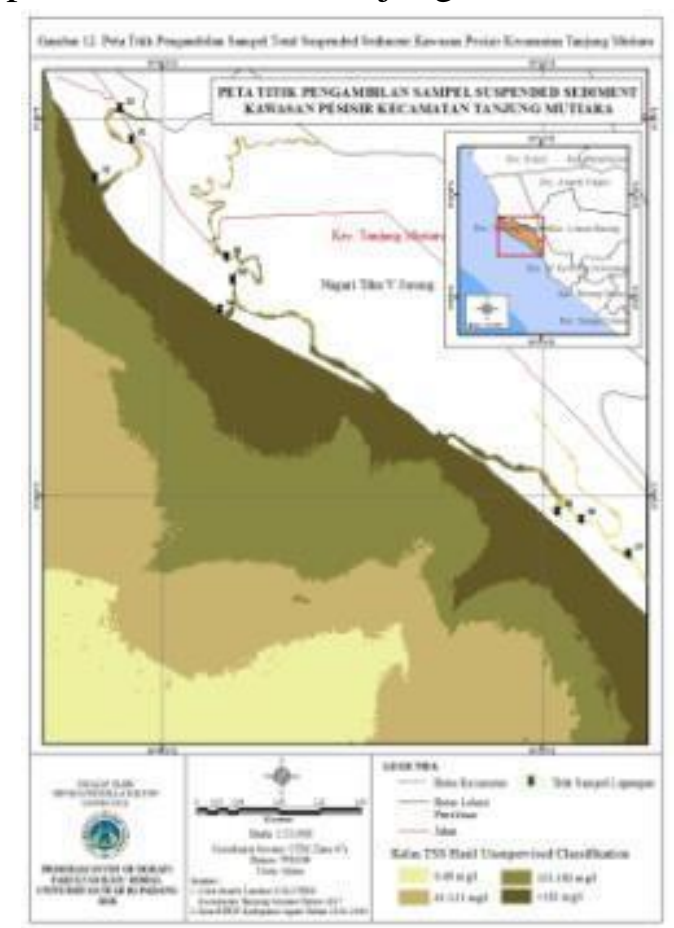

Gambar 5. Peta Titik Pengambilan Sampel Lapangan

Sumber : Hasil Analisis Citra Landsat 8 OLI/TIRS Tahun 2017

b. Prediksi Nilai TSS Menggunakan Algoritma Transfor masi Citra

1) Total Suspended Sediment Tahun 1993

Luas sebaran dan nilai TSS pada tahun 1993 yang terbagi menjadi 4 kelas yaitu kelas I dengan rentang nilai antara 0 - 17,5 mg/l seluas 1533,06 Ha, kelas II dengan rentang nilai antara 18,5 - 36 mg/l seluas 5139,63 Ha, kelas III dengan rentang nilai 37 - 54,5 mg/l seluas 950,4 Ha dan kelas IV dengan nilai >55,5 mg/l seluas 461,79 Ha. 
Nilai konsentrasi TSS pada tahun 1993 berdasarkan analisis citra masih berada dibawah ambang batas ketentuan dari Menteri Lingkungan Hidup. Berdasarkan interpretasi citra, tumbuhan mangrove yang hidup pada kawasan pesisir Kecamatan Tanjung Mutiara masih dikategorikan banyak, sehingga kondisi tersebut menjadi salah satu faktor yang menyebabkan nilai konsentrasi TSS masuk kedalam kategori rendah dan sangat rendah.

Gambar 6 merupakan peta Total Suspended Sediment pada daerah penelitian yang diperoleh dari analisis citra landsat 5 TM tahun 1993, dimana peta tersebut menjelaskan mengenai konsentrasi dan sebaran TSS tahun 1993 pada kawasan pesisir pantai Kecamatan Tanjung Mutiara.

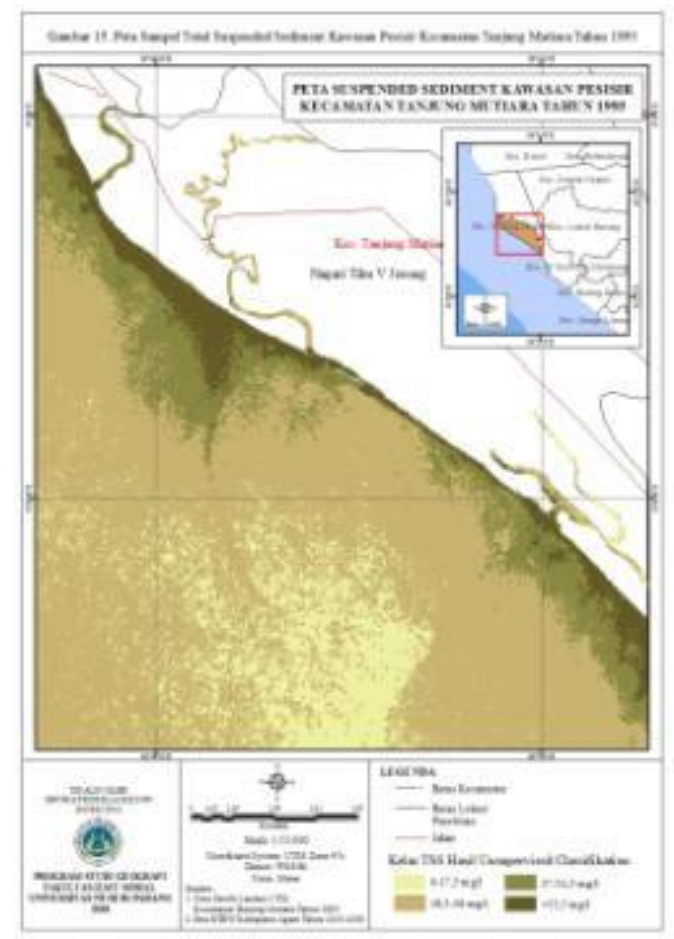

Gambar 6. Peta Suspended Sediment Tahun 1993

Sumber : Hasil Analisis Citra Landsat 5 TM Tahun 1993

\section{2) Total Suspended Sediment Tahun 2005}

Luas sebaran dan nilai TSS pada tahun 2005 yang terbagi menjadi 4 kelas yaitu kelas I dengan rentang nilai antara 0 - 18,5 mg/l seluas 796,59 Ha, kelas II dengan rentang nilai antara 19,5 - 38 mg/l seluas 5016,24 Ha, kelas III dengan rentang nilai 38 - 57,5 mg/l seluas 1821,42 Ha dan kelas IV dengan nilai $>58,5 \mathrm{mg} / \mathrm{l}$ seluas 700,38 $\mathrm{Ha}$.

Nilai konsentrasi TSS pada tahun 2005 berdasarkan analisis citra juga masih berada dibawah ambang batas ketentuan dari Menteri Lingkungan Hidup sama hal nya dengan periode tahun sebelumnya. Namun, pada tahun 2005 nilai maksimum konsentrasi TSS meningkat menjadi $73,85 \quad \mathrm{mg} / \mathrm{l}$ dibandingakan pada tahun 1993 sebesar 69,99 mg/l.

Berdasarkan interpretasi citra, tumbuhan mangrove yang hidup pada kawasan pesisir Kecamatan Tanjung Mutiara mengalami penurunan luas, sehingga kondisi tersebut menjadi salah satu faktor yang menyebabkan nilai maksimum konsentrasi TSS tahun 2005 meningkat dari periode tahun sebelumnya namun masih dalam kategori rendah. Selain itu, faktor perubahan penggunaan lahan pada daerah hulu juga mempengaruhi meningkatnya nilai konsentrasi TSS pada wilayah ini.

Gambar 7 merupakan peta Total Suspended Sediment pada daerah penelitian yang diperoleh dari analisis citra landsat 5 TM tahun 2005, dimana peta tersebut menjelaskan mengenai konsentrasi dan sebaran TSS tahun 
2005 pada kawasan pesisir pantai Kecamatan Tanjung Mutiara.

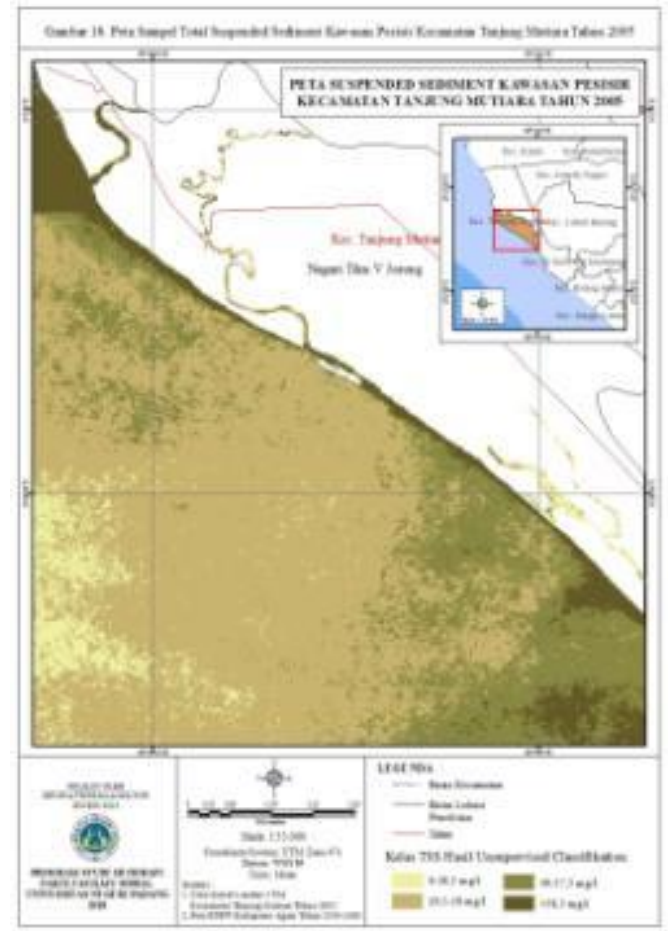

Gambar 7. Peta Suspended Sediment Tahun 2005

Sumber : Hasil Analisis Citra Landsat 5 TM Tahun 2005

\section{3) Total Suspended Sediment} Tahun 2017

Luas sebaran dan nilai TSS pada tahun 2017 yang terbagi menjadi 4 kelas yaitu kelas I dengan rentang nilai antara 0 - $60 \mathrm{mg} / \mathrm{l}$ seluas $1717,56 \mathrm{Ha}$, kelas II dengan rentang nilai antara $61-121$ $\mathrm{mg} / \mathrm{l}$ seluas 2687,67 Ha kelas III dengan rentang nilai 122 - $182 \mathrm{mg} / \mathrm{l}$ seluas 2011,95 Ha dan kelas IV dengan nilai $>183 \mathrm{mg} / \mathrm{l}$ seluas 1544,4 Ha.

Dari hasil interpretasi citra, nilai konsentrasi TSS tahun 2017 terus meningkat disebabkan karena tutupan lahan mangrove terus mengalami kerusakan dan pengurangan luas akibat penebangan serta alih fungsi lahan.

Gambar 8 merupakan peta Total Suspended Sediment pada daerah penelitian yang diperoleh dari analisis citra landsat 8 OLI/TIRS tahun 2017 , dimana peta tersebut menjelaskan mengenai konsentrasi dan sebaran TSS tahun 2017 pada kawasan pesisir pantai Kecamatan Tanjung Mutiara.

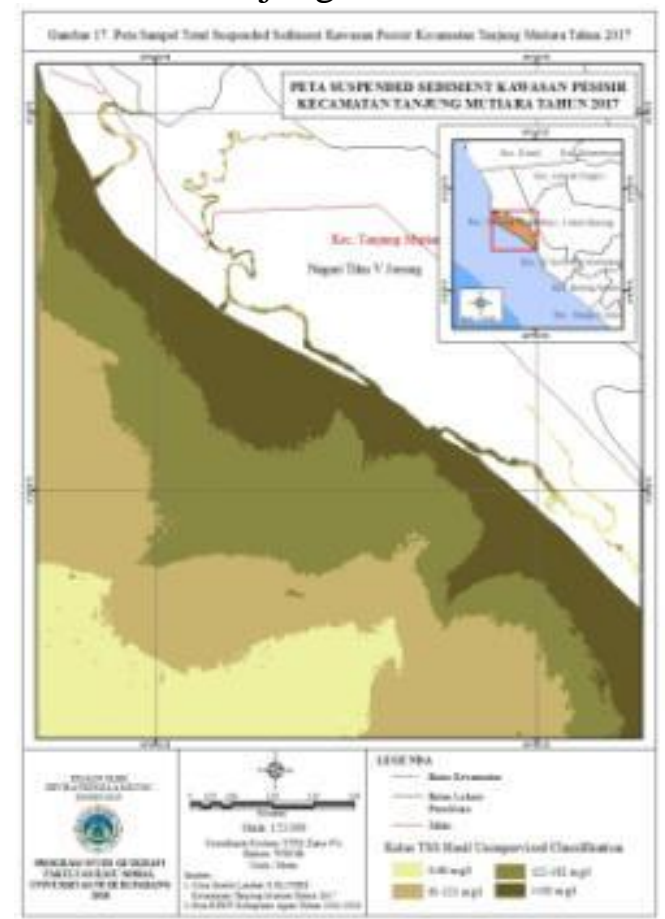

Gambar 8. Peta Suspended Sediment Tahun 2017

Sumber : Hasil Analisis Citra Landsat 8 OLI/TIRS Tahun 2017

Berdasarkan dari hasil analisis citra total suspended sediment kawasan pesisir Kecamatan Tanjung Mutiara pada tahun 1993, tahun 2005 dan tahun 2017, maka diperoleh informasi mengenai klasifikasi TSS selama 3 periode.

Peningkatan luas sebaran TSS sangat terlihat pada TSS kelas III dan IV, dimana pada tahun 1993 luas TSS kelas III seluas 950,5 Ha, kemudian pada tahun 2005 meningkat menjadi seluas 1821,41 Ha dan pada tahun 2017 menjadi seluas 2011,95 Ha. Sedangkan kelas IV luas sebaran TSS pada tahun 1993 seluas 461,79 Ha, kemudian meningkat menjadi seluas $700,38 \mathrm{Ha}$ 
dan pada tahun 2017 meningkat menjadi seluas 1544,4 Ha. Sedangkan pada kelas I dan II pada 3 periode tersebut luas sebaran TSS mengalami penurunan.

Dari hasil interpretasi citra landsat mengenai total suspended sediment tahun 1993, 2005, hingga 2017, terlihat bahwa nilai konsentrasi TSS pada kelas I dan kelas II cendrung mengalami penurunan luas sebaran, sementara kelas III dan kelas IV mengalami peningkatan dan penambahan luas sebaran dan yang menjadi salah satu faktor penyebab hal tersebut terjadi dikarenakan semakin berkurangnya luas tutupan lahan mangrove pada kawasan pesisir Kecamatan Tanjung Mutiara.

Tumbuhan mangrove biasanya hidup pada daerah yang datar dan air yang cukup tenang, keberadaan mangrove pada kawasan pesisir akan memperlambat arus yang masuk dan keluar dari daerah tempat mangrove itu tumbuh, sehingga menyebabkan sedimen yang terbawa oleh arus sungai atau laut akan berhenti dan di endapkan pada kawasan hutan mangrove oleh akar-akar mangrove. Hal tersebut yang membuat konsentrasi TSS pada kawasan hutang mangrove yang banya lebih rendah dari pada konsentrasi TSS

Tabel 3. Dinamika Garis Pantai Dari Tahun 1988 - 1993

\begin{tabular}{|c|c|}
\hline Kode & $\begin{array}{c}\text { Rata-rata perubahan } \\
(\mathrm{m})\end{array}$ \\
\hline Ms & 87,9 \\
\hline An & 76,41 \\
\hline UL & 67,15 \\
\hline Total rata-rata & 77,15 \\
\hline
\end{tabular}

Sumber :Hasil Anlisis Citra Landsat 5 TM Tahun 1988 Dan 1993

Tabel 4. Dinamika Garis Pantai Dari Tahun 1993 - 2005

\begin{tabular}{|c|c|}
\hline Kode & $\begin{array}{c}\text { Rata-rata } \\
\text { perubahan }(\mathrm{m})\end{array}$ \\
\hline Ms & 38,46 \\
\hline An & 50,51 \\
\hline UL & 43,94 \\
\hline Total Rata-rata & 44,30 \\
\hline
\end{tabular}


Sumber :Hasil Anlisis Citra Landsat 5 TM Tahun 2005

Tabel 5. Dinamika Garis Pantai Dari Tahun 2005 - 2017

\begin{tabular}{|c|c|}
\hline Kode & $\begin{array}{c}\text { Rata-Rata } \\
\text { Perubahan (M) }\end{array}$ \\
\hline Ms & 65,53 \\
\hline An & 44,50 \\
\hline UL & 68,08 \\
\hline Total Rata-rata & 59,37 \\
\hline
\end{tabular}

Sumber :Hasil Anlisis Citra Landsat 8 OLI/TIRS Tahun 2017

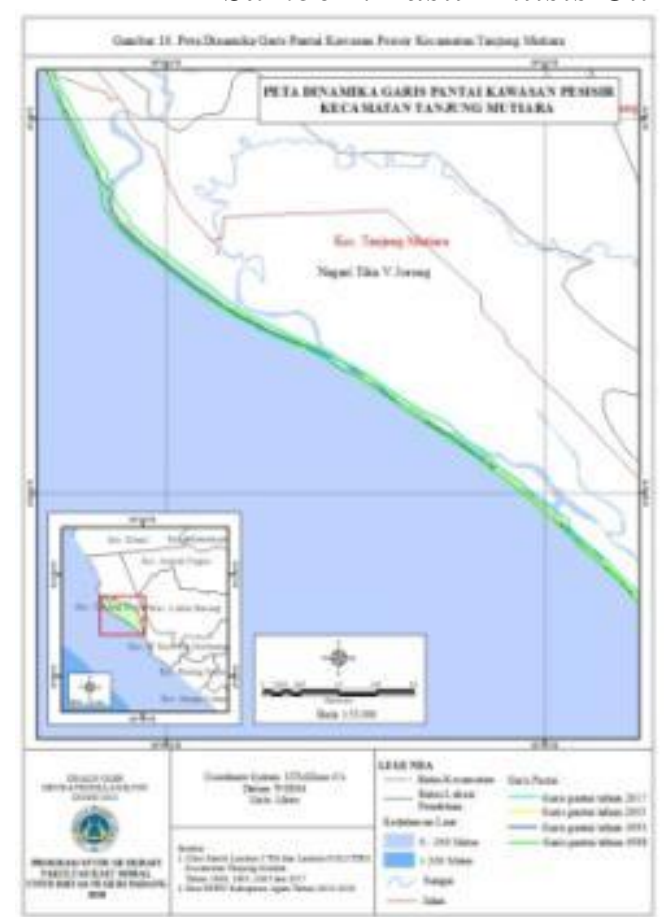

Gambar 9. Dinamika Garis Pantai Tahun 1988 s/d 2017

Sumber :Hasil Anlisis Citra Landsat 5 TM dan Landsat 8 OLI/TIRS Tahun 2017

\section{d. Pengaruh Perubahan Luas} Tutupan Lahan Mangrove dan Total Suspended Sediment Terhadap Dinamika Garis Pantai

Peningkatan konsentrasi sedimen tersuspensi dapat disebabkan oleh kerusakan lahan pada daerah hulu atau pun akibat penurunan luas tutupan lahan mangrove pada daerah pesisir yang mana akar pohon mangrove memiliki fungsi dalam mengikat sedimen dan kemudian mengendapkannya sehingga lama-kelamaan akan membentuk lahan baru.

Indeks kerapatan tuupan lahan mangrove merupakan variabel bebas $\left(\mathrm{X}_{1)}\right.$, dimana indeks kerapatan mangrove pada masing-masing periode tahun diberi bobot 1 untuk kelas jarang, bobot 2 untuk kelas cukup rapat, bobot 3 untuk kelas rapat dan bobot 4 untuk kelas sangat rapat. TSS juga merupakan variabel bebas $\left(\mathrm{X}_{2}\right)$, dimana konsentrasi TSS pada masing-masing periode tahun diberi bobot 4 untuk kelas I, bobot 3 untuk kelas II, bobot 2 untuk kelas III dan bobot 1 untuk kelas IV.

Dinamika garis pantai merupakan variabel terikat $(Y)$, dimana nilai ratarata perubahan garis pantai dari tahun 1988 hingga tahun 1993 sebesar 77,15 $\mathrm{m}$, sedangkan nilai rata-rata perubahan garis pantai dari tahun 1993 hingga tahun 2005 sebesar $44,30 \mathrm{~m}$, dan nilai rata-rata perubahan garis pantai pada tahun 2005 hingga tahun 2017 sebesar $59,57 \mathrm{~m}$.

Analisis regresi linier sederhana dan regresi linier berganda dalam penelitian ini dilakukan dengan menggunakan software SPSS vers 16.

Berdasarkan analisis diketahui bahwa koefisien regresi X sebesar 0,370 menyatakan bahwa setiap penambahan 
$1 \%$ nilai luas mangrove, maka nilai garis pantai bertambah sebesar 0,370. Koefisien regresi tersebut bernilai positif, sehingga dapat dikatakan bahwa arah pengaruh variabel luas mangrove terhadap variabel garis pantai adalah positif.

Berdasarkan nilai signifikansi diperoleh nilai sebesar $0,005<0,05$, sehingga dapat disimpulkan bahwa variabel mangrove (variabel $\mathrm{X}$ ) berpengaruh terhadap variabel garis pantai (variabel Y).

Berdasarkan hasil perhitungan nilai korelasi (R), diketahui bahwa nilai korelasi antara kerapatan mangrove dengan TSS adalah 1.00 dimana nilai tersebut menunjukkan bahwa adanya korelasi sempurna antar kedua variabel tersebut. Dari output tersebut diperoleh koefisien determinansi ( $\mathrm{R}$ Square) sebesar 1,00 yang dapat diartikan bahwa pengaruh variabel bebas atau kerapatan mangrove terhadap variabel terikat atau TSS adalah sebesar $100 \%$.

Berdasarkan hasil analisis koefisien regresi $\mathrm{X}$ sebesar -1 menyatakan bahwa setiap penambahan $1 \%$ nilai kerapatan mangrove, maka nilai TSS bertambah sebesar 1 . Koefisien regresi tersebut bernilai negatif, sehingga dapat dikatakan bahwa arah pengaruh variabel kerapatan mangrove terhadap variabel TSS adalah negatif.

Berdasarkan nilai signifikansi diperoleh nilai sebesar $0,00<0,05$, sehingga dapat disimpulkan bahwa variabel kerapatan mangrove (variabael $\mathrm{X})$ berpengaruh terhadap variabel TSS (variabel Y).
Berdasarkan hasil perhitungan nilai korelasi (R) di atas, diketahui bahwa nilai korelasi antara kerapatan mangrove dengan TSS adalah 0,124 dimana nilai tersebut menunjukkan bahwa tidak adanya korelasi antar kedua variabel tersebut. Dari output tersebut diperoleh koefisien determinansi ( $\mathrm{R}$ Square) sebesar 0,015 yang dapat diartikan bahwa pengaruh variabel bebas atau kerapatan mangrove terhadap variabel terikat atau TSS adalah sebesar $1,5 \%$.

Berdasarkan hasil analisis Koefisien regresi $X$ sebesar 0,043 menyatakan bahwa setiap penambahan $1 \%$ nilai TSS, maka nilai garis pantai bertambah sebesar 0,043. Koefisien regresi tersebut bernilai negatif, sehingga dapat dikatakan bahwa arah pengaruh variabel TSS terhadap variabel garis pantai adalah negatif.

Berdasarkan nilai signifikansi diperoleh nilai sebesar 0,092>0,05, sehingga dapat disimpulkan bahwa variabel TSS (variabael $\mathrm{X}$ ) tidak berpengaruh terhadap variabel garis pantai (variabel Y).

Berdasarkan hasil analisis statistik regresi linier berganda yang sudah dilakukan sebelumnya, maka dapat disimpulkan bahwa :

1) Terdapat pengaruh antara luas tutupan lahan mangrove terhadap dinamika garis pantai :

H1 diterima yang berarti terdapat pengaruh antara variabel X1 atau variabel mangrove terhadap variabel $\mathrm{Y}$ atau variabel garis pantai.

2) Terdapat pengaruh TSS terhadap dinamika garis pantai : 
H1 ditolak yang berarti tidak terdapat pengaruh variabel X2 atau variabel TSS terhadap variabel X2 atau variabel garis pantai.

3) Terdapat pengaruh tutupan lahan mangrove dan TSS terhadap dinamika garis pantai :

H1 diterima yang berarti terdapat pengaruh variabel $\mathrm{X} 1$ atau mangrove dan variabel $\mathrm{X} 2$ atau TSS secara simultan terhadap variabel $\mathrm{Y}$ atau garis pantai sebesar $90,5 \%$.

\section{PENUTUP}

\section{Kesimpulan}

Berdasarkan deskripsi data dan pembahasan hasil penelitian yang telah dikemukakan pada bab IV maka dapat diambil kesimpulan tentang pengaruh tutupan lahan mangrove terhadap total suspended sediment kawasan pesisir Kecamatan Tanjung Mutiara Kabupaten Agam sebagai berikut:

a. Luas tutupan lahan mangrove pada kawasan pesisir Kecamatan Tanjung Mutiara pada tahun 1993 memiliki luas 885,95 Ha, sedangkan pada tahun 2005 mengalami pengurangan luas sebesar 341,72 $\mathrm{Ha}$ sehingga luasnya menjadi $544,23 \mathrm{Ha}$ dan tahun 2017 mengalami pengurangan luas sebesar 216,26 sehingga luasnya menjadi 327,97 Ha. pengurangan ini disebabkan oleh alih fungsi lahan dan penebangan liar.

b. Nilai rata-rata konsentrasi TSS tahun 1993 sebesar 20,31 mg/l, tahun 2005 sebesar $27,71 \mathrm{mg} / \mathrm{l}$ dan tahun 2017 sebesar 105,11 mg/l. Nilai TSS setiap periode waktu rata-rata mengalami peningkatan, hal ini juga disebabkan alih fungsi lahan dan penurunan luas tutupan lahan mangrove akibat abrasi pantai dan pemanfaatan mangrove tanpa memperhatikan kelestariannya.

c. Garis pantai kawasan pesisir Kecamatan Tanjung Mutiara dari tahun 1988 hingga tahun 1993 mengalami pengurangan garis pantai selebar 77,15 m. Garis pantai kawasan pesisir Kecamatan Tanjung Mutiara dari tahun 1993 hingga tahun 2005 telah mengalami perubahan selebar 44,30 m. Tahun 2005 hingga 2017 pada kawasan pesisir pantai Kecamatan Tanjung Mutiara telah mengalami pengurangan garis pantai dengan total perubahan sebesar 59,37 m. Perubahan garis pantai diperkirakan terjadi akibat pengikisan oleh tenaga angin dan air.

d. berdasarkan analisis regresi diketahui bahwa a) H1 diterima yang berarti terdapat pengaruh antara variabel X1 atau variabel mangrove terhadap variabel $\mathrm{Y}$ atau variabel garis pantai. b) $\mathrm{H} 2$ ditolak yang berarti tidak terdapat pengaruh variabel $\mathrm{X} 2$ atau variabel TSS terhadap variabel X2 atau variabel garis pantai. c) H3 diterima yang berarti terdapat pengaruh variabel $\mathrm{X} 1$ atau mangrove dan variabel $\mathrm{X} 2$ atau TSS secara simultan terhadap variabel $\mathrm{Y}$ atau garis pantai sebesar $90,5 \%$.

\section{Saran}

a. Pemerintah dan masyarakat harus lebih peduli lagi terhadap kelestarian hutan mangrove. Hutan mangrove memberikan dampak positif bagi lingkungan, contohnya seperti dapat 
menjaga stabilitas garis pantai, mengikat sedimen dan mengurangi tingkat kekeruhan, serta bermanfaat bagi ekonomi masyarakat. Oleh karena itu, pemerintah harus berupaya untuk melestarikan hutan mangrove dengan cara membuat kebijakan tentang pelestarian hutang mangrove dan memberikan pemahaman serta penyuluhan kepada masyarakat agar terus melestarikan hutan mangrove.

b. Nilai TSS atau tingkat kekeruhan air pada daerah penelitian semakin lama semakin meningkat. Hal tersebut lambat laun dapat mempengaruhi ekosistem kawasan pesisir, oleh karena itu pemerintah dan masyarakat harus menjaga kelestarian hutan pada daerah hulu DAS dan kelestarian hutan mangrove pada daerah muara sungai, karena tumbuhan mangrove memiliki fungsi memerangkap sedimen tersuspensi dan memperlambat arus yang masuk dan keluar dari kawasan hutan mangrove sehingga sedimen tersebut lama kelamaan akan di endapkan dan menjadi lahan baru.

c. Selain pemasangan batu grid, permasalahan abrasi pantai pada kawasan pesisir Kecamatan Tanjung Mutiara dapat diatasi dengan melakukan penanaman mangrove. Beberapa jenis mangrove yang berasal dari marga Avicennia, Sonneratiaceae dan Rhizoporaceae merupakan pohon mangrove yang bisa hidup disepanjang garis pantai dan berfungsi melindungi garis pantai serta mempercepat penambahan daratan. d. Bagi peneliti selanjutnya, sebelum menentukan lokasi penelitian dan penentuan titik lokasi pengambilan sampel TSS sebaiknya penelitian memiliki pengetahuan mengenai kondisi lapangan untuk mempermudah jalannya penelitian.

e. Kawasan pesisir Kecamatan Tanjung Mutiara memiliki berbagai macam permasalahan yang bisa diteliti, salah satunya berkaitan dengan kondisi air sungai pada kawasan hutan mangrove yang terletak di daerah Ujung Labung, dimana peneliti menemukan bahwa pada kawasan hutan mangrove tersebut tingkat kekeruhan air masuk dalam kategori rendah namun kondisi air sungai bewarna kuning hingga kecoklatan. Hal tersebut menandakan bahwa dalam air terdapat kandungan zat terlarut yang mempengaruhi warna air sungai tersebut. selain itu, dalam penelitian ini peneliti membatasi pengambilan sampel TSS hanya pada air permukaan saja, untuk kajian lebih mendalam bisa dilakukan dengan meneliti kandungan TSS pada bagian dasar dan tengah perairan.

\section{DAFTAR PUSTAKA}

Ghufran. (2012). Ekosistem Mangrove : Potensi, Fungsi, dan Pengelolaan. Jakarta: PT Rineka Cipta.

Effendy, M. (2009). Pengelolaan Wilayah Pesisir Secara Terpadu. Jurnal Kelautan , 1-2.

MENLH. (2004). Baku Mutu Air Laut. Keputusan Menteri Negara Lingkungan Hidup Nomor 51 Tahun 2004. 
Presiden RI. (2007). Pengelolaan Wilayah Pesisir dan Pulau-pulau Kecil. Undang-undang Republik Indonesia Nomor 27 Tahun 2007.

Lukman. (2016, Juni 6). Abrasi di Tanjung Mutiara Rusakkan Hutan Mangrove. Retrieved Januari 5, 2017, from Singgalang Padang: https://hariansinggalang.co.id

Ermanto. (2016, Oktober 1). Puluhan Hektar Hutan Bakau di Agam Rusak. Retrieved Januari 5, 2017, from beritasatu.com: http://www.beritasatu.com 